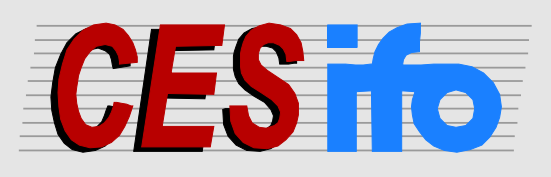

\title{
Working
}

Papers

www.cesifo.org/wp

\section{The Effects of Tuition Fees on Transition from High School to University in Germany}

\author{
Kerstin Bruckmeier \\ Berthold U. Wigger
}

CESIFO WORKING PAPER NO. 4237

CATEGORY 5: ECONOMICS OF EDUCATION

MAY 2013

An electronic version of the paper may be downloaded

- from the SSRN website:

- from the RePEc website:

- from the CESifo website:

WWW.SSRN.com

www.RePEc.org

www.CESifo-group.org/wp

\section{CESifo}




\title{
The Effects of Tuition Fees on Transition from High School to University in Germany
}

\begin{abstract}
This paper studies whether the introduction of tuition fees at public universities in some German states had a negative effect on enrollment, i.e., on the transition of high school graduates to public universities in Germany. In contrast to recent studies, we do not find a significant effect on aggregate enrollment rates. Our study differs from previous studies in three important ways. First, we take full account of the fact that tuition fees were both introduced and abolished in the German states at different points in time. Second, we consider control variables, which are absent in previous studies but turn out to have a significant impact on the evolution of enrollment rates. Third, we allow for state-specific effects of tuition fees on enrollment rates. We conclude that there is no evidence for a general negative effect of the recent introduction of tuition fees on enrollment in Germany.
\end{abstract}

JEL-Code: H750, I220, I280.

Keywords: tuition fees, enrollment rates, treatment effect.

Kerstin Bruckmeier

Karlsruhe Institute of Technology

Chair of Public Economics

and Public Finance

Kronenstraße 34

Germany - 76133 Karlsruhe

kerstin.bruckmeier@kit.edu
Berthold U. Wigger

Karlsruhe Institute of Technology

Chair of Public Economics

and Public Finance

Kronenstraße 34

Germany-76133 Karlsruhe

berthold.wigger@kit.edu

April 30, 2013

Sponsored by the German Federal Ministry of Education and Research (BMBF) (grant no. 01PW11015). Any opinions expressed here are those of the authors. 


\section{Introduction}

Higher education at public universities in Germany was free of charge until 2005. After a ruling of the German constitutional court, which allowed the German states to introduce tuition fees, seven out of the sixteen German states started to charge tuition fees at public universities in 2006 and 2007, respectively. From the start, tuition fees faced severe political opposition. As a consequence, they have already been abolished in five of the seven states that introduced them and, in the remaining two states, abolishment of fees is on the political agenda.

A major argument against tuition fees is that they negatively affect the willingness to study. So far, however, empirical evidence on the effect of tuition fees on the willingness to study in Germany is scarce. Apart from a couple of papers that either provide anecdotal evidence or rely on descriptive statistics, there are only a few papers that try to identify a significant effect of the introduction of tuition fees on the transition of high school graduates to university. These papers provide rather mixed evidence. Helbig et al. (2012) find no such effects of the introduction of tuition fees. The analysis of these authors, however, is based on data that merely considers the intention of high school students to enroll at university. Hübner (2012), in contrast, considers factual enrollment numbers. This author identifies a significantly negative effect of tuition fees on enrollment rates in fee-introducing states that amounts to 2.7 percentage points in comparison to fee-free states. ${ }^{1}$

Empirical evidence for the US and the UK tends to support such a negative relationship. ${ }^{2}$ The German case, however, differs substantially from both the US and the UK case. Firstly, tuition fees in Germany are/were rather modest in comparison to fees in the US and the UK they only amount/ed to 1,000 Euro per year on average. Secondly, the introduction of tuition fees was accompanied by a very comprehensive and generous public student loans program. Thirdly, a substantial share of university students are/were exempted from tuition because of

\footnotetext{
${ }^{1}$ Combining this result with a theoretical model on spillovers between fee states and fee-free states, Hübner (2012) even concludes that the negative effect of tuition fees on enrollment rates in fee states is closer to -4.7 percentage points than to -2.7 percentage points.

${ }^{2}$ Based on a meta analysis of several studies between 1967 and 1982, Leslie and Brinkman (1987) conclude that an increase of $\$ 100$ in college costs per year reduces the enrollment rate by 0.6 to 0.8 percentage points. Heller (1997) examines the results of several studies for the US between 1975 and 1996. This author reports a negative effect on the enrollment rate of 5 to 10 percentage points for a $\$ 1,000$ increase in tuition fees. Kane (1994) considers enrollment between 1972 and 1988 and provides evidence that an increase in direct college costs of $\$ 1,000$ led to a decline of 4.6 to 1.2 percentage points in enrollment rates of white high school graduates. Hemelt and Marcotte (2008) consider enrollment in public four-year colleges between 1991 and 2007 and find a negative effect on enrollment rates of 2.5 percentage points for a $\$ 1,000$ increase in tuition fees. Dearden et al. (2011) show for the UK that a $£ 1,000$ increase in tuition fees results in a decrease in enrollment rates of 3.9 percentage points.
} 
specific social criteria. ${ }^{3}$ Lastly, since only seven out of sixteen German states introduced fees, high school graduates still had the opportunity to study free of charge in Germany. ${ }^{4}$ At first glance, all these arguments suggest that the impact of the introduction of tuition fees, if any, should be smaller than the one found in the US or in the UK. ${ }^{5}$

In light of the scarce, mixed and, to some extent, surprising results of earlier papers we restudy the effect of tuition fees on enrollment rates in Germany. We follow the work of Hübner (2012) and estimate the impact of the implementation of tuition fees employing a difference-in-differences approach. In contrast to Hübner (2012), however, we extend the difference-in-differences approach by explicitly controlling for different trends in the number of new high school graduates in the German states, specific high school reforms in some German states ("G-8-Abitur"), and a number of labor market variables. Furthermore, we take full account of the fact that tuition fees were both introduced and abolished in the German states at different points in time. We show that the result of a negative effect of tuition fees on enrollment rates does not hold in such a more comprehensive framework. While the number of new high school graduates and the high school reforms significantly affect the enrollment rate, the effect of tuition fees on this figure vanishes. In a further step, we disaggregate the tuition effect by considering state-specific effects of tuition fees on enrollment rates. We find significant effects for some but not all states. Yet, some of the significant state-specific effects even point to a positive impact of tuition fees on enrollment rates. This also supports the view that the result of a negative and substantial effect of tuition on enrollment rates in Germany may be doubted.

The remainder of the paper is organized as follows. Section 2 provides a brief overview of the institutional background of higher education financing in Germany. Section 3 describes the data basis employed in this paper. Section 4 considers a simple difference-in-differences approach similar to Hübner (2012). Section 5 establishes a more comprehensive difference-indifferences model and compares the results with the results of Section 4. Section 6 briefly concludes.

\footnotetext{
${ }^{3}$ In Bavaria, for instance, this share amounted to 31 per cent of all students in the winter term 2010; see Bayerisches Staatsministerium für Wissenschaft, Forschung und Kunst (2011).

${ }^{4}$ Although the results of Alecke and Mitze (2012) and Dwenger et al. (2012) suggest that the introduction of tuition fees in Germany has not led to a substantial increase in interstate of mobility of students.

${ }^{5}$ This view also finds support by a study of Canton and de Jong (2005), who consider university enrollment in the Netherlands between 1950 and 1999. These authors only find a weak negative effect of tuition fees and argue that this is due to the fact that tuition fees are comparatively low.
} 


\section{Institutional Background}

In Germany most universities are public. Although responsibility for the organization, administration and funding of higher education lies primarily with the sixteen German states, tuition fees were banned by federal law until 2005. Students only had to pay administrative fees of approximately 75 Euro per semester. In 2005, the Federal Constitutional Court decided that the law prohibiting tuition fees is against the constitution. After the court's decision, seven of the sixteen German states introduced tuition fees of about 500 Euro per semester, although in most of these states tuition fees were only charged for a short period of time. Five states have abolished tuition fees in the meantime. Table 1 gives an overview of the introduction and abolishment of tuition fees in the states.

Table 1: Introduction and abolishment of tuition fees in the 16 German states

\begin{tabular}{lcc}
\hline State & fees since... & fee-free since... \\
\hline Baden-Wuerttemberg & Spring 2007 & Spring 2012 \\
Bavaria & Spring 2007 & - \\
Hesse & Fall 2007 & Fall 2008 \\
Hamburg & Spring 2007 & Fall 2012 \\
Lower-Saxony & Fall 2006 & - \\
North Rhine-Westphalia & Fall 2006 & Fall 2011 \\
Saarland & Fall 2007 & Spring 2010 \\
Berlin & - & - \\
Brandenburg & - & - \\
Bremen & - & - \\
Mecklenb.-Western Pommerania & - & - \\
Rhineland-Palatinate & - & - \\
Saxony & - & - \\
Saxony-Anhalt & - & - \\
Schleswig-Holstein & - & - \\
Thuringia & - & - \\
\hline
\end{tabular}




\section{Data on enrollment behavior}

Our empirical analysis uses data about the individual enrollment behavior of high school graduates collected by the Federal Statistical Office. The data offers information on the number of high school graduates in state $i, G_{i}$, and that part of $G_{i}$ who enroll at a public university (regular or applied sciences) in Germany, $F_{i}$. We calculate the average transition rate of high school graduates for each state by $P_{i}=F_{i} / G_{i}$, which measures the share of graduates in state $i$ who enroll at a public university in Germany. Note that $P_{i}$ includes high school graduates in state $i$ who either enroll at a university in state $i$ or at a university in some other state $j \neq i$. We thus consider enrollment after interstate migration of students.

As Table 2 shows, the available data allows us to distinguish between students who make an immediate transition to university and students who begin their studies in one of the following years. Most high school graduates begin their studies in the year of their graduation, but the share of male students who begin one year after graduation is also very high. Within our observation period, male students were obliged to do a military service, and most students did it before they went to university. With the available data it is possible to either compute transition rates for immediate transition or for cohorts of graduates. In line with previous studies we consider immediate transition. Considering cohorts would result in the loss of observations, since the data is right censored.

\begin{tabular}{|c|c|c|c|c|c|c|}
\hline \multirow[b]{2}{*}{ Year } & \multirow{2}{*}{\multicolumn{2}{|c|}{ High school graduates }} & \multicolumn{4}{|c|}{ Transition to higher education institutions, years after graduation } \\
\hline & & & $\begin{array}{l}\text { immediate } \\
\text { transtition }\end{array}$ & 1 year & 2 years & 3 years \\
\hline \multirow[t]{2}{*}{2007} & male & 202601 & 61872 & 64855 & 23629 & 18986 \\
\hline & female & 231580 & 86403 & 38504 & 10287 & 10086 \\
\hline \multirow[t]{2}{*}{2008} & male & 205829 & 68056 & 67162 & 22874 & - \\
\hline & female & 236262 & 90916 & 41797 & 9973 & - \\
\hline \multirow[t]{2}{*}{2009} & male & 210688 & 73876 & 68291 & - & - \\
\hline & female & 238747 & 96985 & 42830 & - & - \\
\hline \multirow[t]{2}{*}{2010} & male & 216574 & 81031 & - & - & - \\
\hline & female & 242282 & 99788 & - & - & - \\
\hline
\end{tabular}

Table 2: Transitions to higher education institutions in Germany

Source: Federal Statistical Office (2012). 


\section{A Simple Difference-in-Differences Approach}

First, we consider a simple difference-in-differences set up similar to Hübner (2012). Enrollment decisions of high school graduates are observed in two groups, a treatment group (graduates living in fee states) and a control group (graduates living in fee-free states), and at two points in time, before and after the policy intervention (introduction of tuition fees). In fee-states, students have to pay 500 Euro per semester on average with very little variation. Therefore, we assume that there is no variation in the amount of fees within states, but only variation across states (fee states and fee-free states). This implies that we have similar treatment intensity in all fee introducing states.

Difference-in-differences estimates of the effect of tuition fees measure the extent to which enrollment rates of the treatment and the control groups have evolved differently after the treatment has taken place. To estimate the treatment effect, denoted by $\lambda$, we employ a pooled OLS regression model similar to Hübner (2012) as follows

$$
P_{i}=\beta_{0}+\lambda \gamma_{i} \tau_{i}+\beta_{1} \gamma_{i}+\beta_{2} \tau_{i}+\varepsilon_{i}
$$

where $P_{i}$ is the average enrollment rate in state $i$ as defined in section $2, \gamma_{i}$ is a dummy variable indicating fee introducing states, $\tau_{i}$ is a dummy variable indicating observations measured after the policy intervention in state $i$, and $\varepsilon_{i}$ is the error term. The treatment effect $\lambda$ measures the strength of the interaction of both dummy variables. The model is estimated by weighted least squares, using as weights the number of graduates in each state.

Lower-Saxony and North Rhine-Westphalia already introduced tuition fees in the winter term 2006, all other fee states introduced fees in the year 2007, Hesse abolished fees in 2008, and some other states followed in 2009 and 2010 (see Table 1). To make our results comparable to earlier studies, we first assume, as in Hübner (2012), that the treatment period consists of the years 2007 and 2008. In our extended framework, introduced in Section 5, we will consider the exact treatment period for each state separately. Table 3 contains the results of the estimation of equation (1).

The second column is a replication of the results of Hübner (2012) and implies a significant and negative treatment effect of 2.7 percentage points on the enrollment rate. Considering Table 4, however, it becomes obvious that enrollment rates in the German states evolved differently - not only between fee states and fee-free states, but also within these two subgroups. In particular, enrollment rates within the two subgroups evolved differently after 
the treatment took place. Therefore, we also estimated equation (1) considering subsamples of the fee states as treatment group. In the third column of Table 3 we restrict the treatment group to the small states Hamburg and Saarland, whereby the control group stays constant. Based on this sample, we find no negative treatment effect. In the last column of Table 3 , the treatment group includes states that we call "stable" states. This group consists of Bavaria, Baden-Wuerttemberg and Lower Saxony; i.e., those states, which still charge tuition fees or only abolished them after the year 2010. Again, we find no significant treatment effect.

Table 3: Estimation results for the simple difference-in-difference estimation

\begin{tabular}{|c|c|c|c|}
\hline \multirow{2}{*}{ Coefficient } & \multicolumn{3}{|c|}{ Treatment Group } \\
\hline & all fee states ${ }^{+}$ & 2 small states ${ }^{++}$ & 3 stable states $^{+++}$ \\
\hline \multirow[t]{2}{*}{$\beta_{0}$} & $0.374 * * *$ & $0.374 * * *$ & $0.374 * * *$ \\
\hline & $(0.0214)$ & $(0.0218)$ & $(0.0217)$ \\
\hline \multirow[t]{2}{*}{$\beta_{1}$} & 0.0454 & 0.0196 & 0.0374 \\
\hline & $(0.0328)$ & $(0.0665)$ & $(0.0633)$ \\
\hline \multirow[t]{2}{*}{$\beta_{2}$} & 0.0123 & 0.0123 & 0.0123 \\
\hline & $(0.00822)$ & $(0.00835)$ & $(0.00831)$ \\
\hline \multirow[t]{2}{*}{$\lambda$} & $-0.0270^{* *}$ & 0.00380 & -0.00940 \\
\hline & $(0.0109)$ & $(0.00880)$ & $(0.00931)$ \\
\hline \multicolumn{4}{|c|}{$\begin{array}{l}(* * * / * * / * /) \text { : indicates significance at the } 1 \%-/ 5 \%-/ 10 \% \text {-level. Robust clustered standard errors in parenth } \\
\text { Control group in all specifications: } 9 \text { not fee introducing states in } 2007 \text {, before-period: years } 2002-2006 . \\
{ }^{+} \text {All Fee States: } 7 \text { fee introducing states }(2007-2008) \text {. } \\
{ }^{++} 2 \text { small states: Hamburg and Saarland. }{ }^{++} 3 \text { stable states: Baden-Wuerttemberg, Bavaria, Lower Saxony. } \\
\text { All models are fit by weighted least squares using as weight the number of graduates in each state. }\end{array}$} \\
\hline
\end{tabular}

Several factors may play a role in explaining why the treatment effect is not robust against variations in the treatment group. One possible reason is that important control variables are not considered. A second possible reason is the definition of the treatment period. Namely, considering the years 2007 and 2008 as the treatment period neglects the fact that two mayor states, North Rhine-Westphalia and Lower Saxony, which in 2006 had a share of 46 percent of all university freshmen, had already introduced tuition in 2006. A third possible reason is that the estimation of an aggregate treatment effect rules out the possibility that the treatment effect varies between the states because of unobserved state-specific heterogeneity. In order to address these issues, we establish in the next section an extended difference-in-differences model that includes additional control variables, considers treatment periods that vary over states and time, and allows for state-specific treatment effects. 
Table 4: Enrollment rates in the 16 German states 2002-2008

\begin{tabular}{|c|c|c|c|c|c|}
\hline \multirow{2}{*}{ State } & \multirow{2}{*}{$\begin{array}{l}\text { Freshman } \\
2006\end{array}$} & \multicolumn{2}{|c|}{ Enrollment rate } & \multirow{2}{*}{ Difference } & \multirow{2}{*}{$\begin{array}{c}\text { Enrollment rate } \\
2008\end{array}$} \\
\hline & & 2002-2006 & 2007 & & \\
\hline \multicolumn{6}{|c|}{ fee states 2007} \\
\hline Hamburg & 1928 & 0,33 & 0,37 & 0,04 & 0,32 \\
\hline Lower-Saxony & 9156 & 0,40 & 0,36 & $-0,04$ & 0,37 \\
\hline North Rhine-Westpha & 26351 & 0,42 & 0,40 & $-0,02$ & 0,39 \\
\hline Hesse & 8594 & 0,45 & 0,42 & $-0,03$ & 0,43 \\
\hline Baden-Wuerttemberg & 14046 & 0,34 & 0,32 & $-0,03$ & 0,36 \\
\hline Bavaria & 16308 & 0,52 & 0,51 & $-0,01$ & 0,54 \\
\hline Saarland & 1592 & 0,53 & 0,56 & 0,04 & 0,54 \\
\hline \multicolumn{6}{|c|}{ fee-free states } \\
\hline Schleswig-Holstein & 3026 & 0,35 & 0,32 & $-0,02$ & 0,33 \\
\hline Bremen & 1005 & 0,43 & 0,41 & $-0,03$ & 0,41 \\
\hline Rhineland-Palatinate & 6705 & 0,50 & 0,51 & 0,01 & 0,54 \\
\hline Berlin & 4631 & 0,35 & 0,36 & 0,01 & 0,38 \\
\hline Brandenburg & 3728 & 0,31 & 0,32 & 0,01 & 0,36 \\
\hline $\begin{array}{l}\text { Mecklenb.-Western } \\
\text { Pommerania }\end{array}$ & 2573 & 0,37 & 0,39 & 0,01 & 0,35 \\
\hline Saxony & 5637 & 0,33 & 0,36 & 0,03 & 0,36 \\
\hline Saxony-Anhalt & 3732 & 0,41 & 0,38 & $-0,03$ & 0,40 \\
\hline Thuringia & 3587 & 0,36 & 0,36 & 0,00 & 0,40 \\
\hline
\end{tabular}

Source: Federal Statistical Office, Nichtmonetäre Hochschulstatistische Kennzahlen, Fachserie 11, Reihe 4.3.1, various issues.

\section{An Extended Difference-In-Differences Model}

The specification of the previous section does not consider the development of the number of new high school graduates in the German states. This would be of no concern if all states had a common trend in new high school graduates before and after treatment. As Table 5 shows, however, this has not been the case.

This table contains data on the development of the number of high school graduates in the 16 German states between 2002 and 2009. Apparently, there is a bias between the eastern states Berlin, Brandenburg, Mecklenburg-Pommerania, Saxony, Saxony-Anhalt, Thuringia and the remaining western states. All western states, except Hesse, have a strong positive trend, while in the eastern states, the number of high school graduates stayed almost constant or declined. The different trends across states can be attributed to different demographic development between eastern and western regions. In the eastern states, birth rates declined sharply after German reunification. Since cohorts that were born at the time of German reunification left high school in 2008 or later, the disproportional decline in the numbers of high school 
graduates in the eastern states coincides with the treatment period. As the control group, i.e., the fee-free states, is dominated by the eastern states, the different trends in the number of high school graduates may translate into different trends in enrollment rates.

Table 5: Trends in high school graduation across the 16 German states 2002-2009

\begin{tabular}{|c|c|c|c|c|c|c|c|c|}
\hline State & 2002 & 2003 & 2004 & 2005 & 2006 & 2007 & 2008 & 2009 \\
\hline \multicolumn{9}{|c|}{ fee states 2007} \\
\hline Hamburg & 100 & 101 & 103 & 107 & 114 & 121 & 131 & 141 \\
\hline Lower-Saxony & 100 & 102 & 106 & 113 & 116 & 127 & 120 & 130 \\
\hline North Rhine-Westphal & 100 & 102 & 108 & 112 & 119 & 123 & 131 & 135 \\
\hline Hesse & 100 & 96 & 100 & 96 & 103 & 103 & 109 & 112 \\
\hline Baden-Wuerttemberg & 100 & 102 & 100 & 106 & 113 & 118 & 123 & 128 \\
\hline Bavaria & 100 & 99 & 101 & 105 & 112 & 119 & 125 & 134 \\
\hline Saarland & 100 & 104 & 106 & 112 & 126 & 119 & 132 & 252 \\
\hline \multicolumn{9}{|c|}{ fee-free states 2007} \\
\hline Schleswig-Holstein & 100 & 101 & 108 & 114 & 122 & 133 & 136 & 146 \\
\hline Bremen & 100 & 104 & 98 & 111 & 120 & 118 & 130 & 129 \\
\hline Rhineland-Palatinate & 100 & 101 & 103 & 108 & 119 & 127 & 132 & 135 \\
\hline Berlin & 100 & 101 & 104 & 108 & 113 & 111 & 115 & 113 \\
\hline Brandenburg & 100 & 95 & 104 & 97 & 102 & 106 & 103 & 112 \\
\hline $\begin{array}{l}\text { Mecklenb.-Western } \\
\text { Pommerania }\end{array}$ & 100 & 99 & 102 & 105 & 111 & 112 & 185 & 94 \\
\hline Saxony & 100 & 98 & 104 & 103 & 105 & 101 & 103 & 92 \\
\hline Saxony-Anhalt & 100 & 99 & 100 & 98 & 92 & 167 & 96 & 79 \\
\hline Thuringia & 100 & 104 & 106 & 106 & 108 & 106 & 104 & 92 \\
\hline
\end{tabular}

Notes: Development of the index of number of high school graduates, year $2002=100$. Source: Federal Statistical Office, Nichtmonetäre Hochschulstatistische Kennzahlen, Fachserie 11, Reihe 4.3.1, various issues.

As Table 5 also shows, there are outliers in the number of high school graduates in Saarland, Mecklenburg-Western Pommerania and Saxony-Anhalt (see bold figures). These outliers are due to state-specific high-school reforms ("G8-Abitur") that had a one-time impact on the number of high school graduates.

In our extended framework, we explicitly take these developments into account by considering enrollment behavior for each state and year and by adding state-specific exogenous control variables that potentially influence enrollment behavior. We estimate the following model of state-specific average enrollment rates: ${ }^{6}$

$$
P_{i t}=\beta_{0}+\lambda_{i} \mathrm{z}_{i t}+\beta X_{i t}+\gamma_{i}+\tau_{t}+\varepsilon_{i t}
$$

\footnotetext{
${ }^{6}$ See Card and Lemieux (2001) for a similar specification with respect to state-specific enrollment rates.
} 
where $\lambda_{i}$ measures the treatment effect in state $i$ and $z_{i t}$ is a fee dummy, which assumes the value one if students had to pay tuition fees in the fall term of year $t$ in state $i$. Therefore, the fee dummy varies over states and time within the group of fee states. For Lower-Saxony and North Rhine-Westphalia the fee dummy equals one already in 2006, and for Hesse the fee dummy equals one only in the year 2007. The vector $X_{i t}$ includes state-specific time-varying control variables to be discussed in the following, $\gamma_{i}$ and $\tau_{t}$ are state fixed effects and year dummies, and $\varepsilon_{i t}$ is the error term. Again, the model is estimated by weighted least squares, using as weights the number of graduates in each state.

As already discussed, the number of high school graduates in each state and year may play an important role for the development of enrollment rates. We therefore consider the log of the number of high school graduates in each state and each year as a control variable. We expect the effect of this variable on enrollment rates to be negative for two reasons. First, the supply of education does not immediately adjust to fluctuations in higher education demand (Card and Lemieux, 2001). As a consequence, the individual chance to get a place at a university declines if the number of high school graduates increases. Second, a higher number of high school graduates may be due to a lower threshold for high school graduation (Kane 1994). To the extent that this implies that the share of those high school graduates increases who are not inclined to pursue university studies, enrollment rates decline.

To capture possible enrollment effects associated with the sharp one-time increase in high school graduates due to the high school reforms ("G8-Abitur"), we also include a dummy variable that assumes the value one in the year before the high-school reform was implemented and is zero otherwise. Note that the sharp increase as such is already captured by the number of high school graduates. What the dummy variable considers is that a substantial share of high school graduates who would have postponed university enrollment in the absence of the high school reform, immediately enroll when they expect that in the next year the number of high graduates and, thus, enrollment figures will sharply increase.

As control variables we further include the unemployment rate and the regional ratio between the average wage for dependent employees with a university degree and high school graduates without a university degree on the state level. Both variables are related to regional labor market conditions and, hence, to the opportunity costs of enrollment in higher education as well as the potential returns of the decision to study. On the one hand, if regional unemployment is high, the opportunity costs of studying are low. In addition, high unemployment raises incentives to study, as job seekers with a university degree are less 
affected by unemployment. On the other hand, higher unemployment may imply a higher risk of human capital investment, to the extent that people with a university degree may also be unemployed. Thus, we are ambivalent with respect to the relationship between the unemployment rate and the decision to study. The wage ratio approximates trends in the expected future returns of studying compared to those who decide not to study. Hence, we expect the wage ratio to have a positive effect on enrollment.

In what follows, we estimate three different specifications of our extended model. In the first specification, we exclude the vector of control variables, $X_{i t}$, and only consider an identical treatment effect for all fee states, that is, we assume $\lambda_{i}=\lambda$. Thus, our first specification only differs from the model in Section 4 in that it considers the exact timing of the treatment period for each state. In our second specification, we include the vector of control variables, $X_{i t}$, but still stick to the assumption that $\lambda_{i}=\lambda$. Finally, in our third specification, we also allow $\lambda_{i}$ to vary between the states.

Table 6 contains the estimation results of these three specifications. As can bee seen, the simple consideration of the exact timing of treatment (specification 1) still leads to a significant negative treatment effect of tuition fees on enrollment, but the drop in the enrollment rate decreases from 2.7 percentage points (see Section 4) to 1.9 percentage points.

Once we include our additional control variables (specification 2), the treatment effect of tuition fees on enrollment rates becomes insignificant. Instead, the variables log(graduates) and high school reform, which measure variations in the number of new high school graduates, become highly significant and have the expected signs. Among the further control variables, only unemployment rate is significant. Since significance is only weak, we refrain from drawing conclusions from the negative sign of the coefficient.

If we consider state-specific treatment effects (specification 3), we find that fee coefficients vary between states in sign and significance. In fact, the hypothesis of equal fee coefficients can be strongly rejected. ${ }^{7}$ No significant effects are found for the three large states Bavaria, Baden-Wuerttemberg and North Rhine-Westphalia. The coefficients for Bavaria and BadenWuerttemberg are not even negative. The small states Hamburg and Saarland have a significant positive effect. Only Hesse and Lower Saxony show a significant negative effect. Among the control variables that are related to the number of new high school graduates the variable $\log$ (graduates) remains highly significant. In contrast, the variable high school

\footnotetext{
${ }^{7}$ An F-test strongly rejects the null hypothesis of equal coefficients for the fee-state-variables $(\mathrm{F}(6,15)=$ 4330.24; Prob $>$ F = 0.0000).
} 
reform becomes insignificant. This may be due to the fact, that high school reforms took place at the states level and are thus captured by the state-specific fee dummies. This supposition finds support in the fact that Saarland is the only fee state in which the high school reform became effective in the treatment period and has a significantly positive treatment effect of tuition fees on the enrollment rate.

Table 6: Estimation results for enrollment rates, 2002-2008

\begin{tabular}{|c|c|c|c|}
\hline \multirow{2}{*}{ Variables } & \multicolumn{3}{|c|}{ Specification } \\
\hline & (1) & $F \quad(2)$ & (4) \\
\hline \multirow[t]{2}{*}{ Fee } & $-0.0189 * *$ & -0.00921 & \\
\hline & $(0.00791)$ & $(0.00986)$ & \\
\hline \multirow[t]{2}{*}{$\log ($ graduates $)$} & & $-0.0707 * * *$ & $-0.0779 * * *$ \\
\hline & & $(0.0234)$ & $(0.0222)$ \\
\hline \multirow[t]{2}{*}{ unemployment rate } & & $-0.807^{*}$ & -0.432 \\
\hline & & $(0.412)$ & $(0.474)$ \\
\hline \multirow[t]{2}{*}{ wage ratio } & & 0.0907 & 0.107 \\
\hline & & $(0.117)$ & $(0.127)$ \\
\hline \multirow[t]{2}{*}{ high school reform } & & $0.0145 * * *$ & 0.00705 \\
\hline & & $(0.00456)$ & $(0.00686)$ \\
\hline year dummies & yes & yes & yes \\
\hline state dummies & yes & yes & yes \\
\hline \multirow[t]{2}{*}{ Fee Hamburg } & & & $0.0244 * *$ \\
\hline & & & $(0.0110)$ \\
\hline \multirow[t]{2}{*}{ Fee Lower Saxony } & & & $-0.0366 * * *$ \\
\hline & & & $(0.00869)$ \\
\hline \multirow{2}{*}{ Fee North-Rhine-Westphalia } & & & -0.0156 \\
\hline & & & $(0.0125)$ \\
\hline \multirow[t]{2}{*}{ Fee Hesse } & & & $-0.0209 * *$ \\
\hline & & & $(0.00736)$ \\
\hline \multirow{2}{*}{ Fee Baden-Wuerttemberg } & & & 0.000591 \\
\hline & & & $(0.00888)$ \\
\hline \multirow[t]{2}{*}{ Fee Bavaria } & & & 0.0119 \\
\hline & & & $(0.00890)$ \\
\hline \multirow[t]{2}{*}{ Fee Saarland } & & & $0.0313 * *$ \\
\hline & & & $(0.0144)$ \\
\hline \multirow[t]{2}{*}{ Constant } & $0.518 * * *$ & $0.791 * *$ & $0.942 * * *$ \\
\hline & $(0.00682)$ & $(0.363)$ & $(0.279)$ \\
\hline Observations & $1,941,037$ & $1,941,037$ & $1,941,037$ \\
\hline R-squared & 0.949 & 0.960 & 0.967 \\
\hline
\end{tabular}


In order to check the robustness of our results, we consider (1) a placebo treatment, (2) anticipatory effects of the treatment, and (3) an extended data basis. For the first two specifications of our extended model we consider a placebo treatment by assuming, that tuition fees were introduced already in the year 2004 in the seven fee introducing states, i.e., one year before the judgment of the constitutional court. Table A1 shows that the fee dummy is insignificant in all specifications. To test whether students anticipated the introduction of tuition fees, we set the tuition fee dummy to 1 in all fee introducing states already in the year 2006. Table A2 shows that the treatment effect is still negative but insignificant in all specifications. Finally, Table A3 contains the results we get with an extended data basis. The extended data basis also includes those high school graduates who only have a qualification to enroll at a university of applied sciences ("Fachhochschulreife"), but not a general qualification to enroll at a regular university ("Allgemeine Hochschulreife"). Again a significant negative treatment effect in all fee states vanishes, if we add additional controls.

\section{Conclusion}

The present paper has studied whether the introduction of tuition fees had a negative effect on enrollment at public universities in Germany. In contrast to previous research that employs the same data, we do not find a significant effect on aggregate enrollment in those German states that introduced tuition fees. Our paper extends previous studies in three important ways. First, we take full account of the fact that tuition fees were both introduced and abolished in the German states at different points in time. Second, we consider control variables which are absent in previous studies but turn out to have a significant impact on the evolution of enrollment rates. Third, we allow for state-specific effects of tuition fees on enrollment rates.

The first extension leads to a smaller but still significant effect of tuition fees on enrollment rates in the fee states. The second extension reveals a significant effect of the number of new high school graduates on enrollment rates and shows that a significant effect of tuition fees on university enrollment vanishes if different trends in the number of new high school graduates between the states are taken into account. In the third extension, we study whether the introduction of tuitions fees led to differing effects of tuition fees on enrollment within the group of the fee introducing states. We find that the treatment effect of tuition fees in fact differs substantially within the group of the fee states. Some states seem to have experienced a negative effect of tuition fees on enrollment, some states seem to have experienced no effect, and some states even seem to have experienced a positive effect. Therefore, and in contrast to 
previous literature, we conclude that there is no evidence for a general negative effect of the recent introduction of tuition fees on enrollment in Germany. 


\section{Literature}

Alecke, B. and T. Mitze (2012): "Studiengebühren und das Wanderungsverhalten von Studienanfängern: eine panel-ökonometrische Wirkungsanalyse". Perspektiven der Wirtschaftspolitik 13 (4), pp. 357-386.

Bayerisches Staatsministerium für Wissenschaft, Forschung und Kunst (2011), Bericht über die Erhebung und Verwendung der Studienbeiträge an den staatlichen Hochschulen in Bayern 2010,http://www.stmwfk.bayern.de/fileadmin/user_upload/PDF/Hochschule/bericht_studienb eitraege_2010.pdf

Canton, E. and F. de Jong (2005): "The demand for higher education in The Netherlands, 1950-1999," Economics of Education Review (24) 6, pp. 651-663.

Card, D. and T. Lemieux (2001): "Dropout and Enrollment Trends in the Postwar Period: WhatWent Wrong in the 1970s?" in: Risky Behavior among Youth: An Economic Analysis, pp. 439-482, National Bureau of Economic Research, Inc.

Dearden, L., E. Fitzsimons and G. Wyness (2011): "The Impact of Tuition Fees and Support on University participation in the UK", IFS Working Papers W11/17, Institute for Fiscal Studies.

Dwenger, N., J. Storck and K.Wrohlich (2012): "Do Tuition Fees Affect the Mobility of University Applicants? Evidence from a Natural Experiment." Economics of Education Review 31(1), pp. 155-167.

Federal Statistical Office (2012), Nichtmonetäre Hochschulstatistische Kennzahlen 1980 2010. Fachserie 11, Reihe 4.3.1.

Federal Statistical Office (2011), Studierende an Hochschulen Wintersemester 2010/11. Fachserie 11, Reihe 4.1.

Federal Statistical Office (2008a), Finanzen der Hochschulen, Fachserie 11, Reihe 4.5, 2008.

Federal Statistical Office (2008b), Monetäre hochschulstatistische Kennzahlen, Fachserie 11, Reihe 4.3.2, 2008.

Federal Statistical Office (2006a), Finanzen der Hochschulen, Fachserie 11, Reihe 4.5, 2006.

Federal Statistical Office (2006b), Monetäre hochschulstatistische Kennzahlen, Fachserie 11, Reihe 4.3.2, 2006.

Heller, D. E. (1997): "Student Price Response in Higher Education: An Update to Leslie and Brinkman." Journal of Higher Education 68 (6), pp. 624-659.

Hemelt, S. and D. Marcotte (2008): "Rising tuition and enrollment in public higher education". IZA-Discussion Paper No. 3827.

Hübner, M. (2012): Do tuition fees affect enrollment behavior? Evidence from a 'natural experiment' in Germany, Economics of Education Review 31 (6), pp. 949-960.

Kane, T. J. (1994): "College Entry by Blacks since 1970: The Role of College Costs, Family Background and Returns to Education”, Journal of Political Economy 120 (5), pp. 878-911.

Leslie, L. and P. Brinkman (1987): "Student price response in higher education: The student demand studies", Journal of Higher Education 58 (2), pp. 181-204.

Spiess, K. and K. Wrohlich (2010): Does distance determine who attends a university in Germany? Economics of Education Review, 29, pp. 470-479. 


\section{Appendix}

Table A1: Estimation results for enrollment rates (equation 2) for a placebo fee introduction in 2004

\begin{tabular}{|c|c|c|}
\hline \multirow[t]{2}{*}{ Variables } & \multicolumn{2}{|c|}{ Specification } \\
\hline & (1) & (2) \\
\hline$\overline{\text { Fee }}$ & $\begin{array}{l}-0.0156 \\
(0.0114)\end{array}$ & $\begin{array}{l}-0.00769 \\
(0.0116)\end{array}$ \\
\hline $\log ($ graduates $)$ & & $\begin{array}{c}-0.0753 * * * \\
(0.0227)\end{array}$ \\
\hline unemployment rate & & $\begin{array}{c}-0.580^{*} \\
(0.330)\end{array}$ \\
\hline wage ratio & & $\begin{array}{c}0.179 \\
(0.124)\end{array}$ \\
\hline year dummies & yes & yes \\
\hline state dummies & yes & yes \\
\hline Constant & $\begin{array}{l}0.521 * * * \\
(0.00891)\end{array}$ & $\begin{array}{c}0.991 * * \\
(0.344)\end{array}$ \\
\hline Observations & $1,941,037$ & $1,941,037$ \\
\hline R-squared & 0.946 & 0.957 \\
\hline
\end{tabular}


Table A2: Estimation results for enrollment rates (equation 2), treatment already in 2006 for all fee introducing states

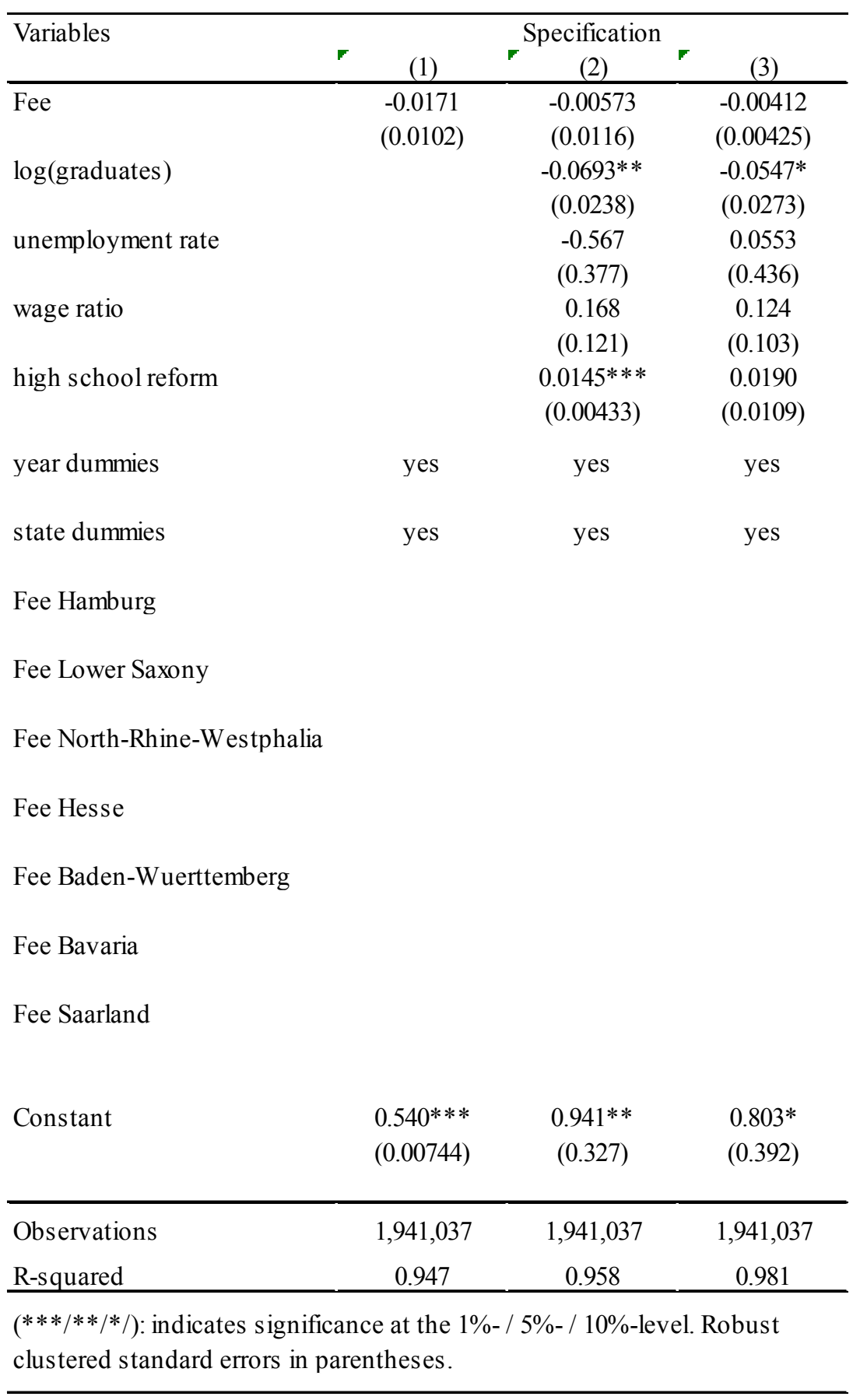


Table A3: Estimation results for enrollment rates for graduates with a qualification for regular universities and universities of applied sciences (equation 2)

\begin{tabular}{|c|c|c|c|}
\hline Variables & (1) & $\begin{array}{c}\text { Specification } \\
(2)\end{array}$ & (4) \\
\hline Fee & $\begin{array}{l}-0.0107^{*} \\
(0.00532)\end{array}$ & $\begin{array}{l}-0.00665 \\
(0.00627)\end{array}$ & \\
\hline $\log$ (graduates) & & $\begin{array}{c}-0.0807 * * * \\
(0.0272)\end{array}$ & $\begin{array}{c}-0.0943 * * * \\
(0.0274)\end{array}$ \\
\hline unemployment rate & & $\begin{array}{l}-0.129 \\
(0.292)\end{array}$ & $\begin{array}{l}-0.0739 \\
(0.280)\end{array}$ \\
\hline wage ratio & & $\begin{array}{l}0.0901 \\
(0.137)\end{array}$ & $\begin{array}{l}0.0599 \\
(0.133)\end{array}$ \\
\hline high school reform & & $\begin{array}{c}0.00607 \\
(0.00395)\end{array}$ & $\begin{array}{l}-2.01 \mathrm{e}-05 \\
(0.00637)\end{array}$ \\
\hline year dummies & yes & yes & yes \\
\hline state dummies & yes & yes & yes \\
\hline Fee Hamburg & & & $\begin{array}{c}0.0438^{* * *} \\
(0.00622)\end{array}$ \\
\hline Fee Lower Saxony & & & $\begin{array}{c}-0.0256^{* * *} \\
(0.00603)\end{array}$ \\
\hline Fee North-Rhine-Westphalia & & & $\begin{array}{c}-0.0115 \\
(0.00829)\end{array}$ \\
\hline Fee Hesse & & & $\begin{array}{c}-0.0283 * * * \\
(0.00529)\end{array}$ \\
\hline Fee Baden-Wuerttemberg & & & $\begin{array}{l}-0.00168 \\
(0.00540)\end{array}$ \\
\hline Fee Bavaria & & & $\begin{array}{l}0.0118 * * \\
(0.00460)\end{array}$ \\
\hline Fee Saarland & & & $\begin{array}{c}0.0127 \\
(0.00863)\end{array}$ \\
\hline Constant & $\begin{array}{l}0.377 * * * \\
(0.00561)\end{array}$ & $\begin{array}{c}1.079 * * * \\
(0.349)\end{array}$ & $\begin{array}{c}1.280^{* * * *} \\
(0.338)\end{array}$ \\
\hline Observations & $2,808,102$ & $2,808,102$ & $2,808,102$ \\
\hline R-squared & 0.958 & 0.964 & 0.974 \\
\hline
\end{tabular}

